\title{
Oestrogens and oestrogen receptors in prostate cancer
}

\author{
Karolina Kowalska and Agnieszka Wanda Piastowska-Ciesielska*
}

\begin{abstract}
The role of androgens in prostate cancer is obvious due to the fact that androgen signalling is the main regulator of prostate growth and function. Androgen deprivation therapy is a mainstay treatment for advanced prostate cancer. However, prostate cancer often becomes androgen-independent, which in consequence leads to lethal and incurable disease. In addition, oestrogens play a crucial role in prostate cancer, especially in elder men in whom the overall ratio of oestrogens to androgens is increasing. This review summarizes the current knowledge on molecular mechanisms through which oestrogens are involved in prostate cancer development. We focused on commonly alternated molecular signalling pathways contributing to tumourgenesis in prostate cancer.
\end{abstract}

Keywords: Oestrogen, Oestrogen receptor a, Oestrogen receptor $\beta$, Prostate cancer

\section{Prostate cancer}

Prostate cancer $(\mathrm{PCa})$ is one of the most common malignance in men in developing countries. In Western countries it is the second cause of death in men, and in the majority of cases it is associated with metastases (Bishop et al. 2015). In recent years the incidences of prostate cancer have been increasing with simultaneous increase in survival rate of the diagnosed patients (Wojciechowska et al. 2015). The progress made in treatment of this disease is probably associated with detection of prostatespecific antigen (PSA) which is currently used as a prognostic marker detected in patients' serum (Stelmach et al. 2011). Although many research studies have been carried out on prostate cancer, detailed molecular mechanism has not been revealed. It is known that age, race, ethnicity or place of living might be causative factors for prostate cancerogenesis. Also diet and lifestyle are recognized as carcinogenic factors (Mahmoud et al. 2015). PCa could be classified on the basis of different morphologic types, of which the most common is adenocarcinoma derived from epithelium, neuroendocrine tumours,

\footnotetext{
*Correspondence: agnieszka.piastowska@umed.lodz.pl Department of Comparative Endocrinology, Faculty of Biomedical Sciences and Postgraduate Training, Medical University of Lodz, Zeligowskiego 7/9, 90-752 Lodz, Poland
}

sarcomas and lymphomas (Wojciechowska et al. 2015). Treatment of the early stages of PCa are usually focused on deprivation of androgens, known as: androgen deprivation therapy (ADT). In advanced stages prostate cancer cells begin to be androgen independent and present higher metastatic potential (Suva et al. 2011).

\section{Oestrogens and oestrogens receptors}

Oestrogens play a crucial role in human development, maintaining sexual and reproductive functions of the organism, as well as influencing the function of cardiovascular, immune, skeletal and central nervous system. The most potent oestrogen produced by the body is 17ß-estradiol (E2) (Heldring et al. 2007). Nevertheless, clinical evidence obtained by Huggins and Hodges showed that oestrogens can influence prostate cancer by inhibiting tumour growth (Huggins and Hodges 1972). Nowadays, oestrogens are used in prostate cancer therapy to reduce follicle-stimulating hormone (FSH) production and decrease stimulation of hypothalamic pituitary by luteinizing hormone (LH), which in consequence reduces androgen synthesis. Although the usage of oestrogens in PCa therapy seems to be favourable, castrate-resistant prostate cancer cells (CRPC) can overcome the mechanisms mentioned above and progress in the disease. Moreover, oestrogen therapy has numerous 
cardiovascular and thrombotic side effects that reduce its clinical use as an alternative to castration (Christoforou et al. 2014).

Cellular signalling of oestrogens is triggered by oestrogen receptors (ERs) $\alpha(E R \alpha)$ and $\beta(E R \beta)$ which are the members of nuclear receptor superfamily (NR) of transcription factors (Christoforou et al. 2014). In prostate ER $\beta$ is present in epithelial cells, whereas ER $\alpha$ in stromal cells (Powell et al. 2012). ERs contain evolutionary conserved structurally and functionally distinct domains, characteristic for the family of nuclear receptors (Fig. 1). DNA-binding domain (DBD) involved in DNA recognition is the central and the most conservative domain. Ligand binding takes part at $\mathrm{COOH}$-terminal multifunctional ligand-binding domain (LBD). The most variable domain is $\mathrm{NH}_{2}$-terminal domain which is also not conserved. Two distinct activation sites: AF- 1 and AF-2 enable transcriptional activation (Heldring et al. 2007).

$E R \alpha$ and ER $\beta$ are products of genes localized on different chromosomes. They have the ability to dimerize with full length ER $\alpha$ and repress AF-1 mediated activity (Wang et al. 2005). In humans five forms of ER $\beta$ were identified ER $\beta 1, E R \beta 2$, ER $\beta 4$ and ER $\beta 5$ in normal prostate cell (Fig. 2; Santamaria-Martinez et al. 2008). Recently, it was suggested that only ER $\beta 1$ isoform may be fully functional, due to the fact that it is the only isoform which may form homodimers or take part in recruitment of coregulatory proteins (Leung et al. 2006). More attention should be placed on ER $\beta 2$ and ER $\beta 5$ isoforms. They have the same sequence as ER $\beta 1$ from exons 1-7 and contain extra sequences with lost AF-2 domain function (Leung et al. 2010). Moreover they can form heterodimers with ER $\beta 1$ isoform after oestrogen stimulation (Leung et al. 2006) or with $E R \alpha$ and through this silence signalling of ER $\alpha$ (Ogawa et al. 1998).

In recent years more attention is paid to oestrogen receptors in prostate cancer indicating that $\mathrm{ER} \alpha$ and ER $\beta$ may play an opposite role in prostate cancer. Firstly, it was suggested that ER $\alpha$ stimulates cell proliferation and transcription and has opposing role to ER $\beta$ whose

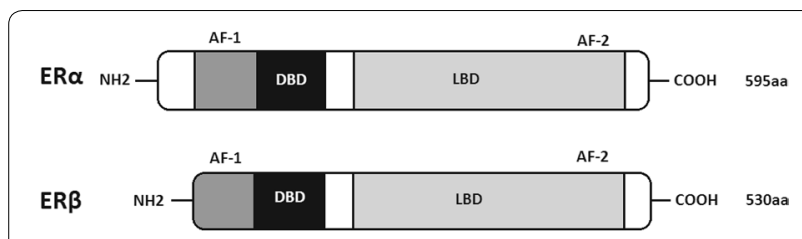

Fig. 1 Schematic representation of oestrogen receptors isoforms: a (ERa) and $\beta$ (ERß). AF-1 and AF-2: distinct transcription activation sites; DBD_DNA-binding domain; LBD—ligand-binding domain; $\mathrm{NH}_{2}-$ and $-\mathrm{COOH}$ are terminal regions of protein; $\mathrm{ERa}$ is 595 amino acids length, ERß 530 amino acids length

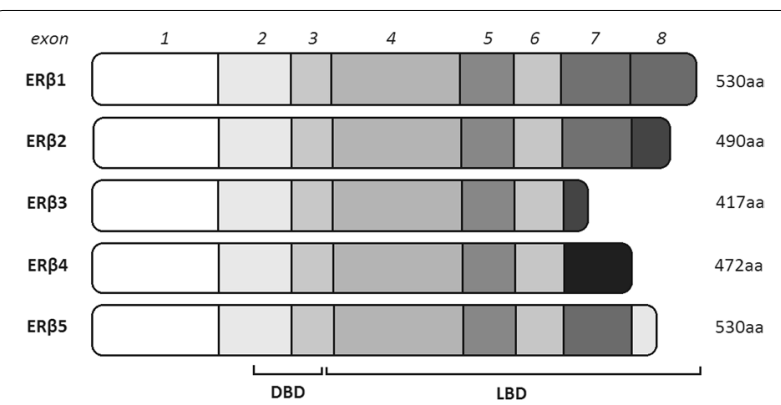

Fig. 2 Schematic structure of oestrogen receptor $\beta(E R \beta)$ isoforms. First six exons are the same in different isoforms. All isoforms share the same DNA-binding domain (DBD) but differ in ligand-binding domains (LBD). On the right side the length of amino acids products is presented

expression is lost during the progression of the disease (Fixemer et al. 2003). Currently, the antiproliferative role of ER $\beta$ is not so obvious due to research presenting that $E R \beta 2$ and ER $\beta 5$ isoforms have tumour-promoting roles (Nelson et al. 2014). ER $\alpha$-knockout mice do not develop prostate cancer after stimulation of testosterone or oestrogens, whereas ER $\beta$-knockout mice do, similarly to the wild type mice (Ricke et al. 2008). Furthermore, ER $\beta 1$ might complex with AR and cause a transcription of ARrelated genes in $\mathrm{PCa}$, what might explain the fact of elevated ER $\beta$ expression in HNPC, corresponding to lower survival of patients (Nelson et al. 2014). Nevertheless, many research studies have been conducted to reveal the detailed molecular mechanism of oestrogen receptors function in PCa.

In this article we reviewed the molecular signalling pathways in which oestrogen receptors are involved in prostate cancer cells (Table 1): cell proliferation and apoptosis as the two pathways mainly altered in carcinogenesis by gene mutations or improper regulation of gene expression (Dey et al. 2012) what can be confirmed by the fact that in human prostate tumours an increase in apoptosis and simultaneous decrease in proliferation are found 1-7 days after castration and retrieval of these markers in some patients is possible after 10 days (Ohlson et al. 2005); then epithelial to mesenchymal transition (EMT) and cell invasiveness as the two processes mainly responsible for metastases which enables prostate cancer cells to engraft in the bone marrow places, as well as the fact that the molecular crosstalk between the prostate tumour and bone stroma in which EMT genes participate is a target of prostate cancer therapies (Smith and Bhowmick 2016); and the chronic inflammation frequently detected in prostate biopsies in patients with increased prostate specific antigen (PSA). Moreover, it was showed that chronic inflammation in benign prostate tissue contributes to high-grade prostate cancer 
Table 1 Summarized biochemical pathways and genes involved in oestrogen signalling in prostate cancer

\begin{tabular}{|c|c|c|c|}
\hline \multicolumn{2}{|c|}{ Gene/signaling pathway } & \multirow[t]{2}{*}{$\begin{array}{l}\text { Oestrogen receptor } \\
\text { type participating in action }\end{array}$} & \multirow[t]{2}{*}{ Author (year) } \\
\hline \multicolumn{2}{|l|}{ Cell proliferation } & & \\
\hline \multirow[t]{2}{*}{ Oncogenes } & BMI-1 & ERß & Mak et al. (2006) \\
\hline & Twist & ERß2 & Dey et al. (2012) \\
\hline \multirow[t]{2}{*}{ Suppressors } & PTEN & ERa & Takizawa et al. (2015) \\
\hline & MAPK & ERa & Takizawa et al. (2015) \\
\hline \multirow[t]{3}{*}{ Cell cycle control } & $\mathrm{p} 21$ & ERß & Colciago et al. (2014) \\
\hline & CCND1 & $\mathrm{ER} \beta$ & Nakamura et al. (2013) \\
\hline & c-Myc & ERß2 & Dey et al. (2012) \\
\hline \multirow[t]{2}{*}{ Signaling pathways } & $\mathrm{PI3} \mathrm{K}$ & ERa & Takizawa et al. (2015) \\
\hline & mTOR & ERa and ER $\beta$ & Wang et al. (2014) \\
\hline \multicolumn{4}{|l|}{ Apoptosis } \\
\hline \multirow[t]{4}{*}{ Proapoptotic } & Bax & $\mathrm{ER} \beta$ & Cheng et al. (2004) \\
\hline & Cleaved caspase-3 & $\mathrm{ER} \beta$ & Cheng et al. (2004) \\
\hline & $p-53$ & ERs & Kanagaraj et al. (2007) \\
\hline & FOXO3 and PUMA & ERß & Dey et al. (2014) \\
\hline Pro/antiapoptotic & TGF- $\beta 1$ & ERs & Chipuk et al. (2001) \\
\hline \multicolumn{4}{|c|}{ Epithelial-mesenchymal transition (EMT) } \\
\hline \multirow[t]{8}{*}{$\downarrow$ EMT } & PHD2/EGLN1 & $E R \beta 1$ & Mak et al. $(2006,2010)$ \\
\hline & HIF1-a & $E R \beta 1$ & Mak et al. $(2006,2010)$ \\
\hline & Snail1 & $E R \beta 1$ & Mak et al. $(2006,2010)$ \\
\hline & Runx 2 & ERß2 & Dey et al. (2012) \\
\hline & TGF- $\beta 1$ & ERß & Hu et al. (2015) \\
\hline & E-cadherin & ER $\beta$ & Hu et al. 2015 \\
\hline & Thbs2 & ERa & Slavin et al. (2014) \\
\hline & MMP3 & & Slavin et al. (2014) \\
\hline \multirow[t]{6}{*}{ 个EMT } & SOX4 & $\mathrm{ER} \beta$ & Mak et al. (2010) \\
\hline & Twist1 & $E R \beta 2$ & Dey et al. (2012) \\
\hline & c-Myc & ERß2 & Dey et al. (2012) \\
\hline & HIF-1a & $E R \beta 2$ and $E R \beta 5$ & Dey et al. (2015) \\
\hline & Runx 2 & $E R \beta 1$ & Dey et al. (2012) \\
\hline & NEAT-1 & ERß & Chakravarty et al. (2014) \\
\hline \multicolumn{4}{|l|}{ Chronic inflammation } \\
\hline \multirow[t]{2}{*}{$\uparrow$} & HIF-1a & ERa & $\begin{array}{l}\text { Ravenna et al. (2009, } \\
\text { 2014) }\end{array}$ \\
\hline & $N F-K B$ & ERa & $\begin{array}{l}\text { Ravenna et al. (2009, } \\
\text { 2014) }\end{array}$ \\
\hline
\end{tabular}

and novel biomarkers for predicting tumour progression due to prostatic inflammation in prostate cancer patients were investigated (Stark et al. 2015).

\section{Prostate cancer cell proliferation}

The role of ER $\alpha$ in prostate cancer cell proliferation is well documented (Fig. 3). Mice lacking ER $\alpha$ did not present aggressive tumour phenotype, contradictory to mice lacking ER $\beta$ (Slusarz et al. 2012). PTEN-deficient mice which are used in prostate cancer studies showed significantly increased expression of ER $\alpha$ in regions were cell proliferation was elevated. Depletion of ER $\alpha$ caused a significant decrease in the size of prostate cancer cell colonies without changing their number. Mitogen-activated protein kinases (MAPK) activity and phosphoinositide 3-kinase (PI3K) signalling pathways are sustained by ER $\alpha$ in prostate cancer (Takizawa et al. 2015). Fujimura et al. (2014) found a relationship between biochemical recurrence, prognoses and ER $\alpha$ expression. ER $\alpha$ counterparts in oestrogen induced translocation of prohibitin (PHB) known to have a significant effect on cell senescence and tumour cell suppression through modulation of 


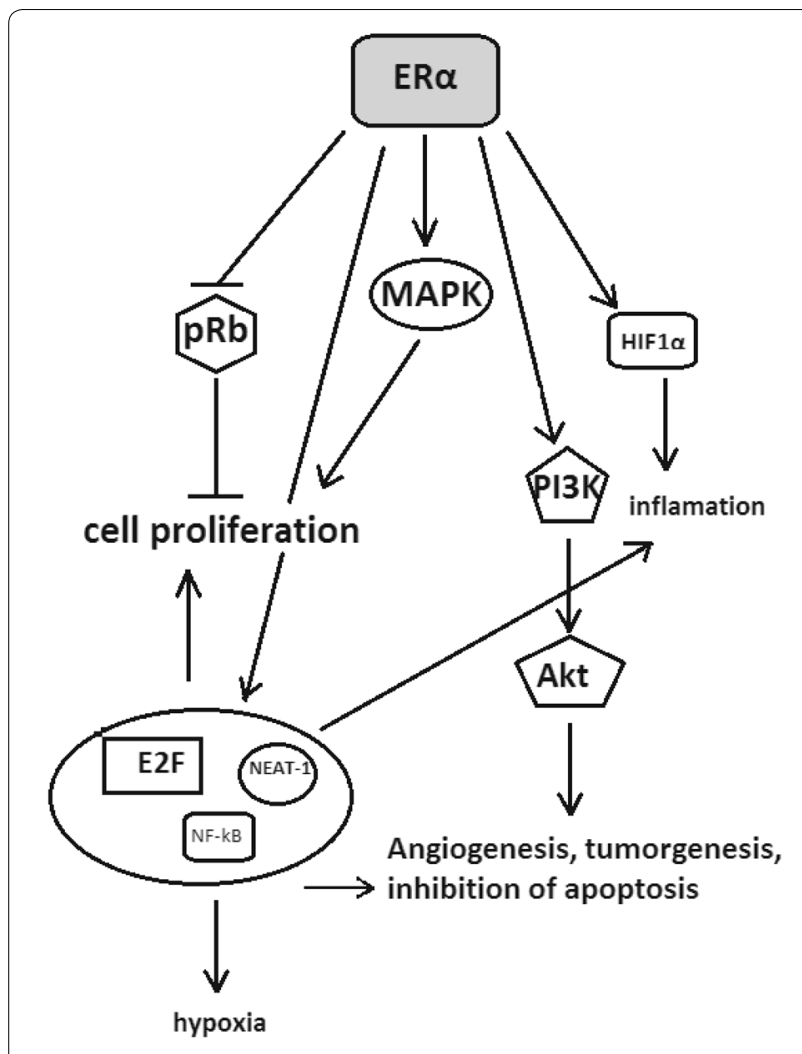

Fig. 3 Summarized cell signalling pathways in which oestrogen receptor a (ERa) takes part (detailed description presented in the text)

retinoblastoma protein $(\mathrm{pRB})$ binding with transcription factors family (E2F) complex which leads to repression of pRb-E2F-associated transcription and cell proliferation. Silencing ER $\alpha$ using siRNA approach was able to suppress PC3 (human prostate cancer adenocarcinoma cell line) cells proliferation and translocation of PHB from mitochondria to the nucleus (Dong et al. 2013). Hariri et al. (2015) have recently shown that low doses of toremifene, a ER $\alpha$ blocker, causes necrosis with high expression of ER $\alpha$ on the stromal surface of the PC3M (cell line derived from a liver metastasis of PC-3 intraspleenic injection in nude mice) cancer cells.

Many research studies are focused on detailed molecular mechanism of ER $\beta$ action in prostate cancer. Moreover, it seems that antiproliferative function of all ER $\beta$ isoforms is not so obvious. In vitro models of prostate adenocarcinoma expressing only ER $\beta$ showed that stimulation of estradiol caused significant reduction of cell proliferation (Corey et al. 2002). Interestingly, cell transfection with ER $\beta 1$ or ER $\beta 2$ revealed that only ER $\beta 1$ isoform inhibits proliferation of prostate cancer cells (Dey et al. 2012). Cell cycle genes play an important role in the control of cell proliferation and tumourgenesis. Cyclin D1 (CCND1) is overexpressed in many types of human cancer including prostate cancer. Interaction between androgens and cell cycle associated proteins was reported by Perry and Tindall in 1996. Like androgens, oestrogens have a capability to modulate cell cycle progression. ER inhibitor ICI 182,780 was reported to influence CCND1 expression and modulate progression to late G1 cell cycle phase (Santamaria-Martinez et al. 2008). The studies by Nakemura et al. (2013) revealed that oestrogens modulate CCND1 expression trough ER $\beta$ via increasing FBJ murine osteosarcoma viral oncogene homolog (FOS) and jun proto-oncogene (JUN) expression in prostate adenocarcinoma PC3 cell line. Cyclin D1-mediated cell cycle pathway might be also modulated by serum/glucocorticoid regulated kinase family member 3 (SGK3)-androgen receptor (AR) expression. Wang et al. documented that in AR-positive cells both ER receptors are involved in regulation of cell cycle through mammalian target of rapamycin (mTOR) signalling pathway (Wang et al. 2014). Nuclear ER $\beta 2$ isoform was reported to have an oncogenic role due to its ability to increase proliferation and expression of twist family bHLH transcription factor 1 (Twist1) and v-myc avian myelocytomatosis viral oncogene homolog (c-Myc) in PC3 and 22Rv1 carcinoma human prostate cancer cell lines (Dey et al. 2012). Endogenous activation of ER $\beta$ in PC3 and DU-145 (prostate carcinoma derived from metastatic site-brain) cells was reported to cause an increase in cyclin-dependent kinase inhibitor 1A (p21) expression and cell cycle arrest indicating that control of proliferation might be governed by cell cycle modulation (Colciago et al. 2014).

In males ER $\beta$ ligand $3 \beta$-Adiol which is a product of $5 \alpha$-reduction of testosterone to $5 \alpha$-dihydrotestosteron (DHT), is present in high levels. Its binding to ER $\beta$ receptor in prostate cancer cells is sufficient to inhibit $\mathrm{PCa}$ proliferation with simultaneous inhibition of migration and invasiveness of PCa cells (Dondi et al. 2010). Another molecular mechanism of cell cycle modulation caused by ER $\beta$ was proposed by Mak et al. They postulated that ER $\beta$ is repressed in prostate cancer through polycomb complex protein BMI-1 (BMI-1), which is induced by phosphatase and tensin homolog (PTEN) deletion. BMI-1 is a well-known oncogene regulating cell proliferation and senescence in prostate tumourgenesis (Mak et al. 2006).

\section{Apoptosis of prostate cancer cells}

Aside from the role of ER $\beta$ in inhibiting PCa cell proliferation and growth, many studies have shown that this oestrogen receptor may be involved in regulation of programmed cell death (Fig. 4). Cheng et al. (2004) suggested that ER $\beta$ is a stronger regulator of cell growth that $\mathrm{ER} \alpha$ in prostate cancer. Moreover, they presented that introduction of ER $\beta$ to DU-145 cell line led to a strong increase in pro-apoptotic protein BCL2-associated X 


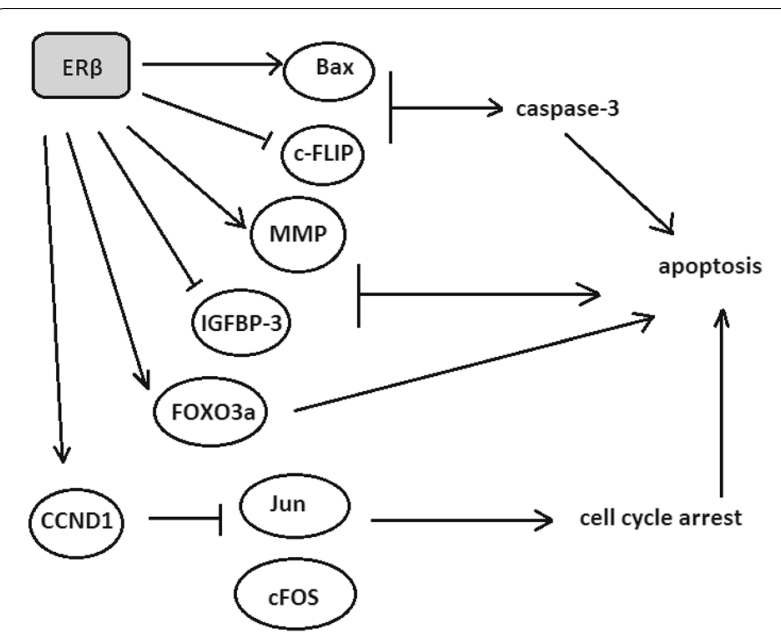

Fig. 4 Summarized cell signalling pathways in which oestrogen receptor $\beta$ (ER $\beta$ ) induces apoptosis in prostate cancer. ER $\beta$ through different pathways induces cell cycle arrest and apoptosis (detailed description is presented above in the text)

protein (Bax) and peri-nuclear expression of cleaved caspase-3. ER $\beta$ might also downregulate c-FLIP (cellular FLICE (FADD-like IL-1 $\beta$-converting enzyme)-inhibitory protein) promoter by binding to $\mathrm{Sp} 1$ site or by modulation of $\mathrm{Sp} 1 / \mathrm{Sp} 3$ ratio through competitive DNA binding, and then promote apoptosis in prostate cells (Yun et al. 2015). Miro et al. (2011) suggested that oxidative stress might be a causative factor in apoptosis. The effect of $\beta$-estradiol on prostate cells in the case of oxidative stress is dependent on $\mathrm{ER} \alpha / \mathrm{ER} \beta$ ratio and might cause an increase in mitochondrial production of reactive-oxygen species (ROS) by repressing the uncoupling proteins (UCPs), which is consistent with previously reported ER $\alpha$ pro- and ER $\beta$ antioncogenic effect. UCPs are involved in the maintenance of mitochondrial membrane potential and ROS production (Valle et al. 2010). It was shown that prolonged increase in $\mathrm{Ca}^{2+}$ concentration may lead to apoptosis. $17 \beta$-estradiol through ERs can cause a concentration-dependent increase in $\mathrm{Ca}^{2+}$ concentration in PC3 cells, thus modulate the activity of $\mathrm{Ca}^{2+}$-dependent enzymes and tumourgenesis of prostate tissue (Huang and Jan 2001). Kanagaraj et al. (2007) found that estradiol causes apoptosis in PC3 cells due to reduced matrix metalloproteinase (MMP) level and increased Insulinlike growth factor-binding protein 3 (IGFBP-3), which was reported to induce apoptosis through tumour protein p53 (p53)-dependent manner. Apoptosis in prostate cancer might be also triggered by ER $\beta$-induced increase in transcription of forkhead box O3 (FOXO3a)-transcription factor known as a tumour suppressor. Increased FOXO3a transcription then causes an increase in PUMA expression (a pro-apoptotic factor p53-upregulated modulator of apoptosis) and triggers apoptosis in prostate cancer cells (Dey et al. 2014). In epithelial prostate cells TGF- $\beta 1$ has been shown to induce apoptosis via release of cytochrome c (Chipuk et al. 2001). There is also evidence presenting that during tumour progression the inhibitory effect of TGF- $\beta 1$ may promote tumour growth via its angiogenic effect. Brodin et al. (1999) suggested that activation of SMAD family member $2(\operatorname{Smad} 2)$ and upregulation of SMAD family member 3, 4, 6 and 7 (Snad3, Smad4, Smad6 and Smad7) are associated with induction of apoptosis in both normal and cancer prostate cells.

\section{EMT and cell invasiveness}

It is well known that high grade $\mathrm{PCa}$ lose their epithelial phenotype and show mesenchymal characteristics, such as expression of vimentin and vascular endothelial growth factor (VEGF), loss of E-cadherin and increase in expression of hypoxia-inducible factor $1 \alpha$ (HIF-1 $\alpha$ ) (Christoforou et al. 2014). The sex determing region Y-box (SOX4) is a transcription factor commonly overexpressed in PCa. Estradiol up-regulates SOX4 expression by formation of ER $\beta$ and AR protein complex. Moreover, clinical data reported in China suggested that overexpression of SOX4 is significantly associated with ER $\beta$ expression and EMT in patients (Yang et al. 2015). ER $\beta 1$ was shown to inhibit EMT by upregulating propyl hydroxylase domain 2 (PHD2/EGLN1) and decreasing hypoxia inducible factor 1 alpha subunit (HIF-1 $\alpha$ ) levels, as well as repressing transcription of vascular endothelial growth factor A (VEGF-A) (Fig. 5). Mak et al. (2010) suggested that ER $\beta 1$ regulates snail family zinc finger 1 (Snail1) via the regulation of glycogen synthase kinase 3 (GSK-3 $\beta$ ) activity, an enzyme that is crucial for regulation of Snail1 localization and stability (Mak et al. $2006,2010)$. On the other hand ER $\beta 2$ was reported to increase invasiveness of $\mathrm{PCa}$ cells trough expression of Twist1 and c-Myc (Dey et al. 2012). ER $\beta 2$ and ER 35 were shown to stabilize HIF-1 $\alpha$ protein and induce hypoxic gene expression indicating its oncogenic effect in PCa (Dey et al. 2015). In vitro studies on PC3 cell line demonstrated that ER $\beta 1$ was able to repress the expression of Runx2, which is known to be involved in bone metastases in prostate cancer, whereas ER $\beta 2$ isoforms triggered a contradictory effect (Dey et al. 2012). Slater et al. (2002) presented data suggesting that increase in $\mathrm{ER} \beta$ receptor might be simultaneous with increase of E-cadherin expression and decrease of TGF- $\beta 1$ in prostate epithelium. Similar effect was observed by Mak et al. (2010) who noted that TGF $\beta 1$ signalling decreased ER $\beta$ expression in both AR-dependent and AR-independent manner. Moreover, ER $\beta$ knock down using shRNA caused a significant increase in EMT (Mak et al. 2010). 


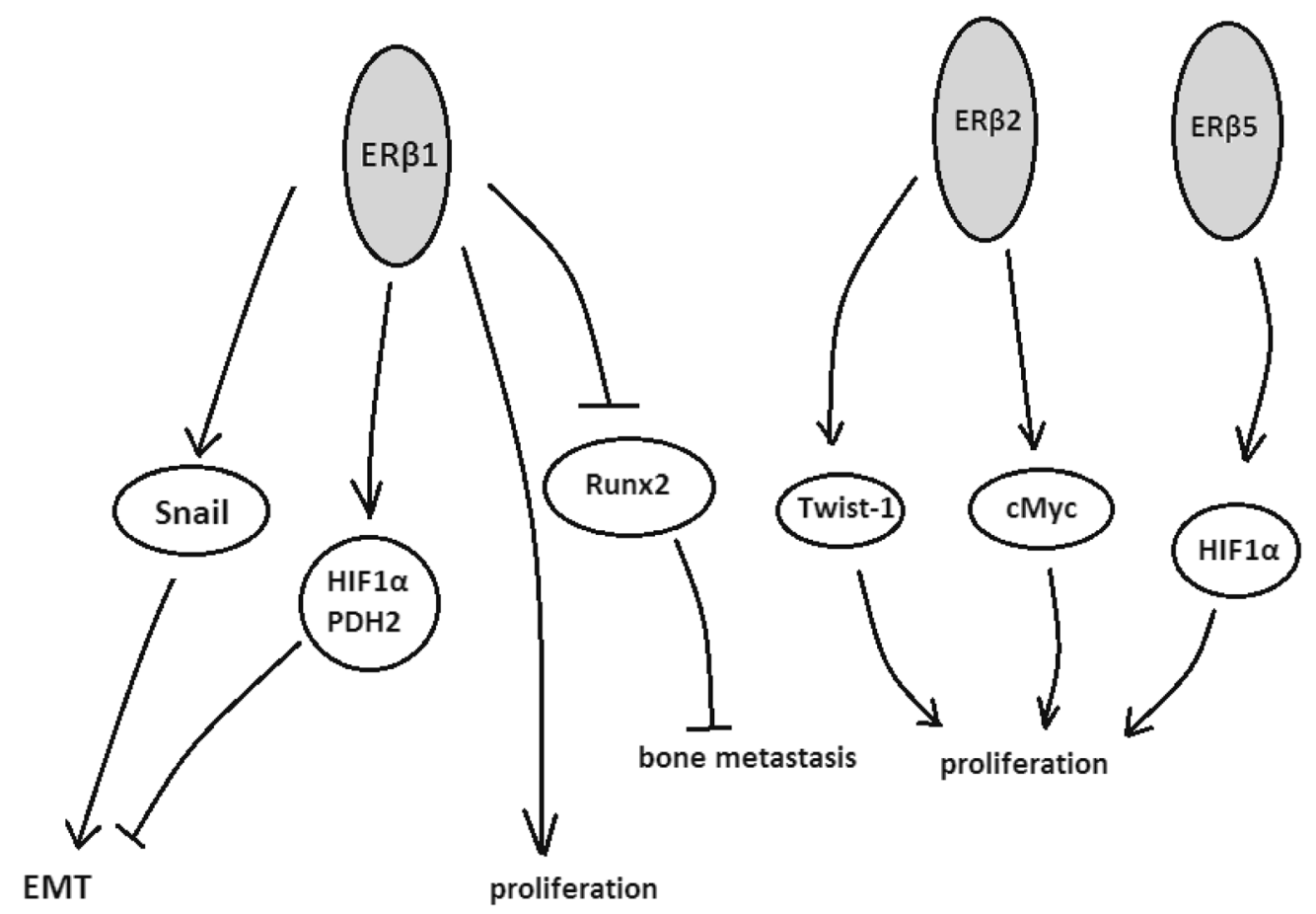

Fig. 5 Schematic cell signalling pathways in which different isoforms of oestrogen receptor $\beta$ (ERß) might be involved in dualistic action in prostate cancer. Different signalling pathways might be associated with different homo- and hetero-dimerization of ERß isoforms (not presented in the figure). Detailed description presented above in the text

Another protein involved in EMT in prostate cancer might be periostin which is also known as osteoblastspecific factor 2 . It was confirmed that periostin is induced by TGF- $\beta /$ STAT3/Twist1 pathway and participates in TGF- $\beta$-induced EMT (Hu et al. 2015). Modulators of oestrogen receptors were shown to decrease cell migration and this effect was reversed by antioestrogens, indicating that anti-migratory action of phytoestrogens is directly associated with ERs (Piccolella et al. 2014). It is known that loss of ER $\beta$ may correlate with the development of poorly differentiated PCa (Slusarz et al. 2012). Mak et al. (2015) suggested a molecular mechanism associated with repression of ER $\beta$ in PCa. ER $\beta$ loss is caused by PTEN deletion, which is one of the most common genetic mutations in prostate cancer. ER $\beta$ transcription is diminished by BMI- 1 which is induced by PTEN deletion. This mechanism cooperates with abovementioned HIF-1/VEGF signalling pathway altered in prostate cancer cells (Mak et al. 2015). Another mechanism associated with ERs in prostate cancer may involve interaction of ERs with nuclear paraspeckle assembly transcript 1 (NEAT-1), a transcriptional regulator which contributes to tumourgenesis. Chakravarty et al. (2014) showed that ER $\alpha$ transcriptionally regulates NEAT1 and promotes prostate tumour progression both in vitro and in vivo. Prostate cancer invasion might be suppressed by cancer-associated fibroblasts (CAFs) in which ER $\alpha$ was reported to modulate thrombospondin 2 (Thbs 2) and matrix metalloproteinase 3 (MMP-3). ER $\alpha$ in CAFs probably decreases invasiveness through decreasing tumour angiogenesis (Slavin et al. 2014).

\section{Chronic inflammation in prostate cancer}

ERs might be also associated with inflammation in prostate cancer. Yatkin et al. (2009) suggested that reduced androgen/oestrogen ratio might induce inflammation in rat prostate. Harris et al. (2000) suggested that oestrogens play a proinflammatory role and high androgen concentration plays a protective role. They showed that 4 days oestrogen treatment caused an increase in interleukin-1 beta, 6 and inflammatory protein 2-alpha (IL-1 $\beta$, IL-6, MIP-2) and inducible nitric oxide synthase (iNOS) levels in in vivo model. Moreover, oestrogens effect on cell inflammation is probably associated with ER $\alpha$ activity. Prins et al. (2001) observed that after treatment with oestrogens inflammation was present only in ER $\beta$-knockout mice, but not in ER $\alpha$-knockout mice. It was suggested that on the molecular level only $E R \alpha$ and epidermal growth factor receptor (EGFR) expression correlates with the levels of all proinflammatory molecules, and HIF1- $\alpha$ and nuclear factor kappa-light-chain-enhancer of activated B cells (NF-kB) are the master regulators of 
hypoxia and inflammation, respectively, in prostate cancer cell lines (Ravenna et al. 2009, 2014).

\section{Oestrogens in prostate cancer therapy}

Androgen deprivation therapy (ADT) is recommended for the treatment of advance prostate cancer patients (Yu et al. 2015). Oestrogens were used as a gold standard in prostate cancer therapy years ago. Many research studies showed that oral oestrogens might increase cardiovascular toxicity which in association with the age of patients limits the usage of oestrogens caused by the effect of the first-pass hepatic metabolism on coagulation (Stein et al. 2012; Langley et al. 2013). Nevertheless, nowadays more attention is paid to oestrogens, due to the fact that gonadotropin-releasing hormone $(\mathrm{GnRH})$ agonists used as a standard treatment have oestrogen-deficiency related side effects (Yu et al. 2015; Stein et al. 2012). It seems that avoidance of the oral administration might limits cardiovascular side effects associated with oestrogens. Thus, parenteral administration of oestrogens might be useful in prostate cancer therapy and might be an alternative to current standard therapy (Langley et al. 2013). The usage of diethylstilbestrol (DES) a synthetic oestrogen was reported to possess acceptable toxicity and might be considered for further clinical studies (Wilkins et al. 2012). Tormifene which belong to second-generation of selective oestrogen receptor modulators (SERMs) was reported to decrease the incidence of new cardiovascular side effects in men younger than 80 years old in ADT treated patients in $80 \mathrm{mg}$ dose (Smith et al. 2011). On the other hand for the dose of tormifene $20 \mathrm{mg}$ no beneficial effect was observed in another study (Taneja et al. 2013). Clinical significance was also established for 2-methoxyoestradiol (2ME2) which possesses anti-angiogenic and anti-proliferative characteristics for patients with CRPC with no beneficial effect observed (Harrison et al. 2011). Interestingly, its analogue ENMD-1198 was recommended for phase II clinical studies as beneficial for patients (Zhou et al. 2011). The agonist of ER $\alpha$ GTx758 significantly decreased oestrogen deficiency side effects during ADT, although it increases the incidence of venous thromboembolism (VTE) (Yu et al. 2015). Thus, more clinical studies should be carried out to exclude potential side effects associated with known oestrogens or to determine the potential usage of the new ones.

\section{Conclusions}

In recent years there is a growing body of evidence that oestrogens play crucial role in prostate tumourgenesis. Here we presented data showing that oestrogen, acting via its receptors, regulates various cellular processes including: proliferation, differentiation, apoptosis, EMT, invasiveness and chronic inflammation in prostate cancer cells. It seems that $\mathrm{ER} \alpha$ possesses oncogenic role in prostate cancer, whereas ER $\beta$ suppressive role has been disputable so far. Now, many research studies have shown that ER $\beta$ isoforms might act differently in prostate cancer indicating that its role is pleiotropic. Taken together, oestrogen plays an important role in prostate carcinogenesis through direct or indirect participation in molecular mechanism which are crucial for tumourgenesis, i.e.: proliferation, cell cycle control, apoptosis or EMT. Further studies are needed to explain all molecular mechanisms of oestrogen signalling in prostate cancer due to their importance in developing new approaches to prostate cancer treatment.

\section{Abbreviations}

2ME2: 2-methoxyoestradiol; ADT: androgen deprivation therapy; AR: androgen receptor; Bax: BCL2-associated X protein; BMI-1: polycomb complex protein BMI-1; CAFs: cancer-associated fibroblasts; CCND1: cyclin D1; c-FLIP: (cellular FLICE (FADD-like IL-1 $\beta$-converting enzyme)-inhibitory protein; cMyc: v-myc avian myelocytomatosis viral oncogene homolog; CRPC: castrate-resistant prostate cancer cells; DBD: DNA-binding domain; DES: diethylstilbestrol; DHT: 5a-dihydrotestosteron; EGFR: epidermal growth factor receptor; EMT: epithelial-mesenchymal transition; ERs: oestrogen receptors; ERa: oestrogen receptor $a$; $E R B$ : oestrogen receptors $\beta$; FOS: FBJ murine osteosarcoma viral oncogene homolog; FOXO3: forkhead box O3; FSH: follicle-stimulating hormone; GnRH: gonadotropin-releasing hormone; GSK-3ß: glycogen synthase kinase 3; HIF-1a: hypoxia inducible factor 1 alpha subunit; IGFBP-3: insulin-like growth factor-binding protein 3; IL-1 3 : interleukin-1 beta; IL-6: interleukin-6; iNOS: inducible nitric oxide synthase; iNOS: nitric oxide synthase; JUN: jun proto-oncogene; LBD: ligand-binding domain; LH: luteinizing hormone LH; MAPK: mitogen-activated protein kinases; MIP-2: inflammatory protein 2-alpha; MMP: matrix metalloproteinases; MMP-3: matrix metalloproteinase 3; mTOR: mammalian target of rapamycin; NEAT-1: nuclear paraspeckle assembly transcript 1; NF-kB: nuclear factor kappa-light-chain-enhancer of activated B cells; NR: nuclear receptor superfamily; p21: cyclin-dependent kinase inhibitor 1A; p53: tumour protein p53; PCa: prostate cancer; PHB: prohibitin; PHD2/ EGLN1: propyl hydroxylase domain 2; PI3K: phosphoinositide 3-kinase; pRB: retinoblastoma protein; PSA: prostate-specific antigen; PTEN: phosphatase and tensin homolog; PUMA: pro-apoptotic factor p53-upregulated modulator of apoptosis; ROS: reactive-oxygen species; SERMs: selective oestrogen receptor modulators; SGK3: serum/glucocorticoid regulated kinase family member 3; Smad2: SMAD family member 2; Smad3: SMAD family member 3; Smad4: SMAD family member 4; Smad6: SMAD family member 6; Smad7: SMAD family member 7; Snail-1: snail family zinc finger 1 ; SOX4: sex determing region Y-box; TGF- $\beta 1$ : transforming growth factor beta; TGF- $\beta 1$ : transforming growth factor $\beta 1$; Thbs 2: thrombospondin 2; Twist-1: twist family bHLH transcription factor 1; UCPs: uncoupling proteins; VEGF: vascular endothelial growth factor; VEGFA: vascular endothelial growth factor A; VTE: venous thromboembolism.

\section{Authors' contributions}

AP-C conceptualized the study. KK conducted the literature survey, study selection and data extraction. KK reviewed the articles and drafted the manuscript. KK and AP-C edited the manuscript. AP-C supervised the study. Both authors read and approved the final manuscript.

\section{Acknowledgements}

This work was supported by the Medical University of Lodz grant 503/0-07804/503-01-002. We thank Prof. Małgorzata Gajewska (Warsaw University of Life Sciences, Department of Physiological Sciences, Warsaw, Poland.), for her help and the correction of the English manuscript.

\section{Competing interests}

The authors declare that they have no competing interests. 
Received: 14 March 2016 Accepted: 19 April 2016 Published online: 26 April 2016

\section{References}

Bishop JL, Davies AH, Ketola K, Zoubeidi A (2015) Regulation of tumor cell plasticity by the androgen receptor in prostate cancer. Endocr Relat Cancer 22(3):R165-R182

Brodin G, ten Dijke P, Funa K, Heldin CH, Landstrom M (1999) Increased smad expression and activation are associated with apoptosis in normal and malignant prostate after castration. Cancer Res 59:2731-2738

Chakravarty D, Sboner A, Nair SS, Giannopoulou E, Li R, Hennig S, Mosquera JM, Pauwels J, Park K, Kossai M, MacDonald TY, Fontugne J, Erho N Vergara IA, Ghadessi M, Davicioni E, Jenkins RB, Palanisamy N, Chen Z, Nakagawa S, Hirose T, Bander NH, Beltran H, Fox AH, Elemento O, Rubin MA (2014) The oestrogen receptor alpha-regulated IncRNA NEAT1 is a critical modulator of prostate cancer. Nat Commun 5:5383

Cheng J, Lee EJ, Madison LD, Lazennec G (2004) Expression of estrogen receptor beta in prostate carcinoma cells inhibits invasion and proliferation and triggers apoptosis. FEBS Lett 566:169-172

Chipuk JE, Bhat M, Hsing AY, Ma J, Danielpour D (2001) Bcl-xL blocks transforming growth factor-beta 1-induced apoptosis by inhibiting cytochrome $\mathrm{c}$ release and not by directly antagonizing Apaf-1-dependent caspase activation in prostate epithelial cells. J Biol Chem 276:26614-26621

Christoforou P, Christopoulos PF, Koutsilieris M (2014) The role of estrogen receptor beta in prostate cancer. Mol Med 20:427-434

Colciago A, Ruscica M, Mornati O, Piccolella M, Montagnani-Marelli M, Eberini I, Festuccia C, Magni P, Motta M, Negri-Cesi P (2014) In vitro chronic administration of ERbeta selective ligands and prostate cancer cell growth: hypotheses on the selective role of 3beta-adiol in AR-positive RV1 cells. Biomed Res Int 2014:801473

Corey E, Quinn JE, Emond MJ, Buhler KR, Brown LG, Vessella RL (2002) Inhibition of androgen-independent growth of prostate cancer xenografts by 17beta-estradiol. Clin Cancer Res 8:1003-1007

Dey P, Jonsson P, Hartman J, Williams C, Strom A, Gustafsson JA (2012) Estrogen receptors beta1 and beta2 have opposing roles in regulating proliferation and bone metastasis genes in the prostate cancer cell line PC3. Mol Endocrinol 26:1991-2003

Dey P, Strom A, Gustafsson JA (2014) Estrogen receptor beta upregulates FOXO3a and causes induction of apoptosis through PUMA in prostate cancer. Oncogene 33:4213-4225

Dey P, Velazquez-Villegas LA, Faria M, Turner A, Jonsson P, Webb P, Williams C, Gustafsson JA, Strom AM (2015) Estrogen receptor beta2 induces hypoxia signature of gene expression by stabilizing HIF-1alpha in prostate cancer. PLOS ONE 10:e0128239

Dondi D, Piccolella M, Biserni A, Della TS, Ramachandran B, Locatelli A, Rusmini P, Sau D, Caruso D, Maggi A, Ciana P, Poletti A (2010) Estrogen receptor beta and the progression of prostate cancer: role of 5alpha-androstane3beta, 17beta-diol. Endocr Relat Cancer 17:731-742

Dong P, Jiang L, Liu J, Wu Z, Guo S, Zhang Z, Zhou F, Liu Z (2013) Induction of paclitaxel resistance by ERalpha mediated prohibitin mitochondrialnuclear shuttling. PLOS ONE 8:e83519

Fixemer T, Remberger K, Bonkhoff H (2003) Differential expression of the estrogen receptor beta (ERbeta) in human prostate tissue, premalignant changes, and in primary, metastatic, and recurrent prostatic adenocarcinoma. Prostate 54:79-87

Fujimura T, Takahashi S, Urano T, Takayama K, Sugihara T, Obinata D, Yamada Y, Kumagai J, Kume H, Ouchi Y, Inoue S, Homma Y (2014) Expression of androgen and estrogen signaling components and stem cell markers to predict cancer progression and cancer-specific survival in patients with metastatic prostate cancer. Clin Cancer Res 20:4625-4635

Hariri W, Sudha T, Bharali DJ, Cui H, Mousa SA (2015) Nano-Targeted Delivery of Toremifene, an Estrogen Receptor-alpha Blocker in Prostate Cancer. Pharm Res 32:2764-2774

Harris MT, Feldberg RS, Lau KM, Lazarus NH, Cochrane DE (2000) Expression of proinflammatory genes during estrogen-induced inflammation of the rat prostate. Prostate 44:19-25
Harrison MR, Hahn NM, Pili R, Oh WK, Hammers H, Sweeney C, Kim K, Perlman S, Arnott J, Sidor C, Wilding G, Liu G (2011) A phase II study of 2-methoxyestradiol (2ME2) NanoCrystal(R) dispersion (NCD) in patients with taxane-refractory, metastatic castrate-resistant prostate cancer (CRPC). Invest New Drugs 29:1465-1474

Heldring N, Pike A, Andersson S, Matthews J, Cheng G, Hartman J, Tujague M, Strom A, Treuter E, Warner M, Gustafsson JA (2007) Estrogen receptors: how do they signal and what are their targets. Physiol Rev 87:905-931

Hu Q, Tong S, Zhao X, Ding W, Gou Y, Xu K, Sun C, Xia G (2015) Periostin mediates TGF-beta-induced epithelial mesenchymal transition in prostate cancer cells. Cell Physiol Biochem 36:799-809

Huang JK, Jan CR (2001) Mechanism of estrogens-induced increases in intracellular $\mathrm{Ca}(2+)$ in PC3 human prostate cancer cells. Prostate 47:141-148

Huggins C, Hodges CV (1972) Studies on prostatic cancer. I. The effect of castration, of estrogen and androgen injection on serum phosphatases in metastatic carcinoma of the prostate. CA Cancer J Clin 22:232-240

Kanagaraj P, Vijayababu MR, llangovan R, Senthilkumar K, Venkataraman P, Aruldhas MM, Arunakaran J (2007) Effect of 17beta-estradiol on apoptosis, IGF system components and gelatinases $A$ and $B$ in prostate cancer cells (PC-3). Clin Chim Acta 377:70-78

Langley RE, Cafferty FH, Alhasso AA, Rosen SD, Sundaram SK, Freeman SC, Pollock P, Jinks RC, Godsland IF, Kockelbergh R, Clarke NW, Kynaston HG, Parmar MK, Abel PD (2013) Cardiovascular outcomes in patients with locally advanced and metastatic prostate cancer treated with luteinising-hormone-releasing-hormone agonists or transdermal oestrogen: the randomised, phase 2 MRC PATCH trial (PR09). Lancet Oncol 14:306-316

Leung YK, Mak P, Hassan S, Ho SM (2006) Estrogen receptor (ER)-beta isoforms: a key to understanding ER-beta signaling. Proc Natl Acad Sci USA 103:13162-13167

Leung YK, Lam HM, Wu S, Song D, Levin L, Cheng L, Wu CL, Ho SM (2010) Estrogen receptor beta2 and beta5 are associated with poor prognosis in prostate cancer, and promote cancer cell migration and invasion. Endocr Relat Cancer 17:675-689

Mahmoud AM, Al-Alem U, Ali MM, Bosland MC (2015) Genistein increases estrogen receptor beta expression in prostate cancer via reducing its promoter methylation. J Steroid Biochem Mol Biol 152:62-75

Mak P, Leung YK, Tang WY, Harwood C, Ho SM (2006) Apigenin suppresses cancer cell growth through ERbeta. Neoplasia 8:896-904

Mak P, Leav I, Pursell B, Bae D, Yang X, Taglienti CA, Gouvin LM, Sharma VM, Mercurio AM (2010) ERbeta impedes prostate cancer EMT by destabilizing HIF-1alpha and inhibiting VEGF-mediated snail nuclear localization: implications for Gleason grading. Cancer Cell 17:319-332

Mak P, Li J, Samanta S, Chang C, Jerry DJ, Davis RJ, Leav I, Mercurio AM (2015) Prostate tumorigenesis induced by PTEN deletion involves estrogen receptor beta repression. Cell Rep 10:1982-1991

Miro AM, Sastre-Serra J, Pons DG, Valle A, Roca P, Oliver J (2011) 17beta-Estradiol regulates oxidative stress in prostate cancer cell lines according to ERalpha/ERbeta ratio. J Steroid Biochem Mol Biol 123:133-139

Nakamura Y, Felizola SJ, Kurotaki Y, Fujishima F, McNamara KM, Suzuki T, Arai Y, Sasano H (2013) Cyclin D1 (CCND1) expression is involved in estrogen receptor beta (ERbeta) in human prostate cancer. Prostate 73:590-595

Nelson AW, Tilley WD, Neal DE, Carroll JS (2014) Estrogen receptor beta in prostate cancer: friend or foe? Endocr Relat Cancer 21:T219-T234

Ogawa S, Inoue S, Watanabe T, Orimo A, Hosoi T, Ouchi Y, Muramatsu M (1998) Molecular cloning and characterization of human estrogen receptor betacx: a potential inhibitor ofestrogen action in human. Nucleic Acids Res 26:3505-3512

Ohlson N, Wikstrom P, Stattin P, Bergh A (2005) Cell proliferation and apoptosis in prostate tumors and adjacent non-malignant prostate tissue in patients at different time-points after castration treatment. Prostate 62:307-315

Piccolella M, Crippa V, Messi E, Tetel MJ, Poletti A (2014) Modulators of estrogen receptor inhibit proliferation and migration of prostate cancer cells. Pharmacol Res 79:13-20

Powell E, Shanle E, Brinkman A, Li J, Keles S, Wisinski KB, Huang W, Xu W (2012) Identification of estrogen receptor dimer selective ligands reveals growth-inhibitory effects on cells that co-express ERalpha and ERbeta. PLOS ONE 7:e30993 
Prins GS, Birch L, Couse JF, Choi I, Katzenellenbogen B, Korach KS (2001) Estrogen imprinting of the developing prostate gland is mediated through stromal estrogen receptor alpha: studies with alphaERKO and betaERKO mice. Cancer Res 61:6089-6097

Ravenna L, Sale P, Di VM, Russo A, Salvatori L, Tafani M, Mari E, Sentinelli S, Petrangeli E, Gallucci M, Di SF, Russo MA (2009) Up-regulation of the inflammatory-reparative phenotype in human prostate carcinoma. Prostate 69:1245-1255

Ravenna L, Principessa L, Verdina A, Salvatori L, Russo MA, Petrangeli E (2014) Distinct phenotypes of human prostate cancer cells associate with different adaptation to hypoxia and pro-inflammatory gene expression. PLoS ONE 9:e96250

Ricke WA, McPherson SJ, Bianco JJ, Cunha GR, Wang Y, Risbridger GP (2008) Prostatic hormonal carcinogenesis is mediated by in situ estrogen production and estrogen receptor alpha signaling. FASEB J 22:1512-1520

Santamaria-Martinez A, Morote J, de Torres I, Bellmunt J, Reventos J, Munell F (2008) Estrogen receptor beta displays cell cycle-dependent expression and regulates the $\mathrm{G} 1$ phase through a non-genomic mechanism in prostate carcinoma cells. Cell Oncol 30:349-365

Slater M, Brown D, Husband A (2002) In the prostatic epithelium, dietary isoflavones from red clover significantly increase estrogen receptor beta and E-cadherin expression but decrease transforming growth factor beta1. Prostate Cancer Prostatic Dis 5:16-21

Slavin S, Yeh CR, Da J, Yu S, Miyamoto H, Messing EM, Guancial E, Yeh S (2014) Estrogen receptor alpha in cancer-associated fibroblasts suppresses prostate cancer invasion via modulation of thrombospondin 2 and matrix metalloproteinase 3. Carcinogenesis 35:1301-1309

Slusarz A, Jackson GA, Day JK, Shenouda NS, Bogener JL, Browning JD, Fritsche KL, MacDonald RS, Besch-Williford CL, Lubahn DB (2012) Aggressive prostate cancer is prevented in ERalphaKO mice and stimulated in ERbetaKO TRAMP mice. Endocrinology 153:4160-4170

Smith BN, Bhowmick NA (2016) Role of EMT in Metastasis and Therapy Resistance. J Clin Med 5:17

Smith MR, Malkowicz SB, Brawer MK, Hancock ML, Morton RA, Steiner MS (2011) Toremifene decreases vertebral fractures in men younger than 80 years receiving androgen deprivation therapy for prostate cancer. J Urol 186:2239-2244

Stark T, Livas L, Kyprianou N (2015) Inflammation in prostate cancer progression and therapeutic targeting. Transl Androl Urol 4:455-463

Stein M, Goodin S, Doyle-Lindrud S, Silberberg J, Kane M, Metzger D, Eddy S, Shih W, DiPaola RS (2012) Transdermal estradiol in castrate and chemotherapy resistant prostate cancer. Med Sci Monit 18:CR260-CR264

Stelmach A, Potemski P, Borówka A (2011) Nowotwory uk3adu moczowop3ciowego; Zalecenia postepowania diagnostyczno-terapeutycznego w nowotworach z3ooliwych. Tom I. Gdansk, Via Medica, pp 295-356
Suva LJ, Washam C, Nicholas RW, Griffin RJ (2011) Bone metastasis: mechanisms and therapeutic opportunities. Nat Rev Endocrinol 7:208-218

Takizawa I, Lawrence MG, Balanathan P, Rebello R, Pearson HB, Garg E, Pedersen J, Pouliot N, Nadon R, Watt MJ, Taylor RA, Humbert P, Topisirovic I, Larsson O, Risbridger GP, Furic L (2015) Estrogen receptor alpha drives proliferation in PTEN-deficient prostate carcinoma by stimulating survival signaling, MYC expression and altering glucose sensitivity. Oncotarget 6:604-616

Taneja SS, Morton R, Barnette G, Sieber P, Hancock ML, Steiner M (2013) Prostate cancer diagnosis among men with isolated high-grade intraepithelial neoplasia enrolled onto a 3-year prospective phase III clinical trial of oral toremifene. J Clin Oncol 31:523-529

Valle A, Oliver J, Roca P (2010) Role of uncoupling proteins in cancer. Cancers (Basel) 2:567-591

Wang Z, Zhang X, Shen P, Loggie BW, Chang Y, Deuel TF (2005) Identification, cloning, and expression of human estrogen receptor-alpha36, a novel variant of human estrogen receptor-alpha66. Biochem Biophys Res Commun 336:1023-1027

Wang Y, Zhou D, Chen S (2014) SGK3 is an androgen-inducible kinase promoting prostate cancer cell proliferation through activation of p70 56 kinase and up-regulation of cyclin D1. Mol Endocrinol 28:935-948

Wilkins A, Shahidi M, Parker C, Gunapala R, Thomas K, Huddart R, Horwich A, Dearnaley D (2012) Diethylstilbestrol in castration-resistant prostate cancer. BJU Int 110:E727-E735

Wojciechowska U, Didkowska J, Zatonski W (2015) Nowotwory z3ooliwe W Polsce w 2012 roku. Nowotw J Oncol 65:166

Yang M, Wang J, Wang L, Shen C, Su B, Qi M, Hu J, Gao W, Tan W, Han B (2015) Estrogen induces androgen-repressed SOX4 expression to promote progression of prostate cancer cells. Prostate 75(13):1363-1375

Yatkin E, Bernoulli J, Talvitie EM, Santti R (2009) Inflammation and epithelial alterations in rat prostate: impact of the androgen to oestrogen ratio. Int J Androl 32:399-410

Yu EY, Getzenberg RH, Coss CC, Gittelman MM, Keane T, Tutrone R, Belkoff L, Given R, Bass J, Chu F, Gambla M, Gaylis F, Bailen J, Hancock ML, Smith J, Dalton JT, Steiner MS (2015) Selective estrogen receptor alpha agonist GTX-758 decreases testosterone with reduced side effects of androgen deprivation therapy in men with advanced prostate cancer. Eur Urol 67:334-341

Yun H, Xie J, Olumi AF, Ghosh R, Kumar AP (2015) Activation of AKR1C1/ERbeta induces apoptosis by downregulation of c-FLIP in prostate cancer cells: a prospective therapeutic opportunity. Oncotarget 6:11600-11613

Zhou Q, Gustafson D, Nallapareddy S, Diab S, Leong S, Lewis K, Gore L, Messersmith WA, Treston AM, Eckhardt SG, Sidor C, Camidge DR (2011) A phase I dose-escalation, safety and pharmacokinetic study of the 2-methoxyestradiol analog ENMD-1198 administered orally to patients with advanced cancer. Invest New Drugs 29:340-346

\section{Submit your manuscript to a SpringerOpen ${ }^{\circ}$ journal and benefit from:}

- Convenient online submission

Rigorous peer review

- Immediate publication on acceptance

- Open access: articles freely available online

- High visibility within the field

- Retaining the copyright to your article

Submit your next manuscript at springeropen.com 